Perinatology pISSN 2508-4887 • elSSN 2508-4895

\section{Original article}

Perinatology Vol. 31, No. 4, December, 2020 https://doi.org/10.14734/PN.2020.31.4.199

\title{
Clinical Characteristics and Outcomes of Mothers and Newborn Babies at an Inte- grated Perinatal Center for High-risk Preg- nancy and Neonatal Care
}

\author{
Youna Park, MD', \\ Mi Hyeon Gang, MD', \\ Yong Wook Lee, MD', \\ Byung Hun Kang, MD, PhD², \\ Min A Lee, MD, PhD², \\ Mea-young Chang, MD, PhD ${ }^{1}$ \\ Departments of ${ }^{1}$ Pediatrics, \\ ${ }^{2}$ Gynecology and Obstetrics, \\ Chungnam National University \\ Hospital, Daejeon, Korea
}

Received: 31 August 2020 Revised: 19 October 2020 Accepted: 5 November 2020

Correspondence to Mea-young Chang, MD, PhD Department of Pediatrics, Chungnam National University Hospital, 282 Munhwa-ro, Jung-gu, Daejeon 35015, Korea

Tel: $+82-42-280-7253$

Fax: +82-42-255-3158

E-mail:mychang@cnuh.co.kr

Copyright@ 2020 by The Korean Society of Perinatology

This is an Open Access article distributed under the terms of the Creative Commons Attribution Non-Commercial License (http://creativecommons.org/ license/by-nc/4.0/), which permits unrestricted non-commercial use, distribution, and reproduction in any medium, provided that the original work is properly cited.
Objective: The appropriate perinatal care and safe delivery of high-risk pregnant women have a significant impact on the prognosis of newborn. The purpose of this study is to analyze the characteristics and outcomes of high-risk pregnant women and their babies in a single integrated care center for high risk pregnancy and neonate care.

Methods: The subjects were babies born in Chungnam national university hospital, their mothers and transferred babies between January 1, 2018 and December 31, 2018. We analyzed the time of transfer, interval between transfer and delivery, clinical features in pregnant women and their babies. The clinical characteristics and outcomes of the babies were compared to those of outborn babies and analyzed according to the timing of the transfer and duration between time of the mother's transfer and delivery.

Results: Mean gestational age at first visit was 26.4 weeks. The average time to delivery after the first visit was 73.1 days. The main reasons for the mother's transfer were fetal problems (17.0\%), obstetric and other underlying diseases of mothers (18.9\%) and various problems related to pregnancy (52.4\%). Babies born in hospital had lower gestational age and birth weight than transferred babies and their main reason for admission was prematurity (65.5\%). The earlier transfer of mothers and longer interval between transfer and delivery were related to lower rate of emergency cesarean section in mothers, lower admission rate and larger gestational age and birth weight in babies.

Conclusions: The early transfer of high-risk pregnant women and their appropriate management can optimize the outcomes of babies as well as mothers.

Key Words: Integrated center, Perinatal care, High-risk pregnancies, High-risk newborns, Transfer of patients

\section{서론}

고위험 임신은 신생아의 사망률 및 이환율을 증가시키는 요인을 수반하는 임신을 의미한 다. 고위험 임신을 잘 관리하는 것은 고위험 신생아에 대한 치료의 향상과 더불어 이들의 예 후 향상에 크게 기여한다.

초혼 연령의 증가, 임산부의 고령화, 보조 생식술로 인한 다태 임신의 증가, 다문화 가정 의 증가 등으로 인하여 고위험 임산부가 지속적으로 증가하고 있다. ${ }^{1}$ 35세 이상 출산 여성 의 비율은 2008년 14.3\%, 2013년 20.2\%, 2018년 31.8\%로 증가하였다. 재태연령 37주 미 만의 조산아는 2008년 5.5\%, 2013년 6.5\%, 2018년 7.8\%로 증가하였고, 출생체중 2,500 g 미만의 저체중아는 2008년 4.9\%, 2013년 5.5\%, 2018년 31.8\%로 증가하였으며, 다태아 는 2008년 2.8\%, 2013년 3.3\%, 2018년 4.2\%로 증가하였다. ${ }^{2}$ 한편, 고위험 임산부의 수 및 전체 임산부에서 차지하는 비율 또한 2011년 35,974명(7.9\%), 2012년 39,146명(8.4\%), 2013년 38,140명(9.0\%), 2014년 41,051명(9.7\%) 등으로 증가하였다. ${ }^{3}$ 
정부는 고위험 임산부에 대한 정책으로 35세 이상 임산부로 서 임신과 관련하여 입원이 필요하다고 의사가 판단한 경우이 거나, 연령에 상관없이 고혈압 질환, 당뇨병, 심부전, 신질환, 다 태임신, 대사 장애를 동반한 임신 과다 구토, 절박 유산, 자궁경 부 무력증, 자궁 및 자궁의 부속기 질환, 자궁 내 성장 지연, 임신 중 복강 내 수술, 분만 전 출혈, 조기진통, 전치태반, 양막의 조기 파열, 태반조기박리, 양수과다증, 양수과소증 등으로 입원한 경 우를 고위험 산모로 정의하고 의료비 경감 정책을 시행하고 있 다. ${ }^{4}$ 또한 2008년부터 신생아집중치료지역센터 사업을 통해 고 위험 신생아 진료에 대한 지원을 시작하였으며 2014년부터는 고위험 산모 ·신생아 통합치료센터 사업을 시작하여 2020년 현재 전국에 19 개의 고위험 산모 · 신생아 통합치료센터가 운영 되고 있다. 정부 지원을 받은 고위험 산모 · 신생아 통합치료센 터가 운영된 지 수년이 되었으나 아직 관련 연구 자료는 부족한 상태로, 본 연구에서는 단일 고위험 산모 - 신생아 통합치료센터 에서 출산하였던 산모와 신생아의 임상적 특징 및 치료 결과를 분석하고자 하였다.

\section{대상 및 방법}

\section{1. 대상}

2018년 1월부터 12월까지 본원에서 출산한 산모 총 554명 중 임신 20주 이후 임신을 중단한 20명을 제외한 534명을 대상 으로 하였다. 임신 20 주 이후 임신 중단된 20 명의 산모 중 11 명 (55\%)이 자궁내 태아사망에 해당하였고 그 외의 이유로는 만삭 전 조기양막파열, 태아 기형 등으로 인한 임신 중단 등이 있었 다. 또한, 본원에서 출생한 신생아(이하 원내 출생아) 620 명과 외부 병원에서 출생 후 전원되어 본원 신생아 중환자실로 입원 하였던 신생아(이하 원외 출생아) 141 명의 자료를 조사하였다. 본 연구는 신생아 의무기록을 후향적으로 분석한 것으로, 연구 자의 동의서 취득이 면제되었으며 충남대학교병원 의학연구심 의위원회의 승인을 받았다(IRB No, 2019-11-014).

\section{2. 자료 수집 및 방법}

산모의 특징으로는 나이, 전원 후 분만까지의 기간, 첫 방문 시 재태연령, 전원 과정, 체외수정을 한 산모의 비율, 다태 임신, 분만 방법을 조사하였다. 본원에 첫 방문 시 경로는 외래 또는 분만실로의 내원으로 나누었고, 전원 시 산모의 주 호소 증상 또 는 전원 이유, 산모의 기저 질환을 조사하였다. 산모의 기저 질 환은 자궁, 난소, 질과 그 주위 회음부의 질환 및 골반내 유착 등 의 산과적 기저 질환과 그 외의 비산과적 기저 질환으로 분류하
였다. 또한 분만 후의 입원 기간, 분만 후 사망 여부 또는 중환자 실 입실 여부, 분만 후 합병증에 대하여 조사하였다.

본원 신생아 중환자실의 입원 기준은 재태연령 35 주 미만, 출 생체중 2,300 g 미만, 그 외에 건강보험심사평가원이 고시한 신 생아 중환자실 입원료 급여 기준에 근거하고 있다. 상기 기준에 따라 원내 출생아 중 정상 신생아실에 머물렀던 군과 신생아 중 환자실에 입원하였던 군, 전원되어 입원한 군으로 나누어 출생 시 재태연령, 출생체중, 성별, 부당경량아의 빈도, 제왕절개율 및 1 분과 5 분 아프가점수 등 신생아의 특징을 조사하였다. 신생 아 중환자실에 입원한 원내 출생아 및 원외 출생아 간에 재태연 령, 출생체중, 성별, 부당경량아의 빈도, 분만 방법, 아프가점수, 입원 시 주 호소, 입실 시 나이 및 체온, 입원 중 호흡 보조의 방 법과 기간, 합병증, 입원 기간 및 입원 중 사망의 빈도를 비교하 였다. 기관지폐이형성증(bronchopulmonary dysplasia, BPD) 은 2001년 National Institute of Child Health and Human Development에서 발표된 New BPD의 정의로 진단하였다. ${ }^{5}$ 최소 28일 이상 산소 치료를 받은 환아를 대상으로 하였고 본 연구에 서는 $\mathrm{BPD}$ 의 중증도는 따로 구분하지 않았다. 뇌출혈은 배아기 기질 출혈(germinal matrix hemorrhage)만 있는 경우는 제외 하였고 초음파, 컴퓨터단층촬영 또는 자기공명영상검사에서 뇌 실 내 출혈(intraventricular hemorrhage) 또는 뇌실질 내 출혈 (intracerebral hemorrhage)이 확인된 경우만 포함하였다. ${ }^{6}$

산모의 전원 시점에 따라 임신 1 분기, 임신 2 분기, 임신 3 분 기의 군으로 나누고, 전원 후 분만까지의 시간에 따라 7 일 이 내, 7 일 이후부터 28 일 이내, 28 일 이상 군으로 분류한 후 각 군 의 산모로부터 출생한 신생아의 입원 비율, 출생 시 재태연령, 출생체중, 부당경량아의 빈도, 제왕절개율, 1 분 및 5 분 아프가 점수, 5 분 아프가점수가 7 점 미만인 환아의 비율을 비교하였다.

\section{3. 통계 분석}

통계 분석은 SPSS version 23.0 통계 프로그램을 이용하였 다. 신생아와 산모의 임상적 특징은 빈도 분석과 기술 분석을 이 용하였다. 원외 출생아와 원내 출생아의 임상적 특징 비교는 선 형 회귀분석과 로지스틱 회귀분석을 사용하였다. 신생아 간의 임상적 특징 비교와 산모의 전원 시점 또는 전원 시점부터 분만 까지 기간에 따른 신생아의 특성 비교는 일원변량분석을 이용 하였다. $P<0.05$ 를 통계적으로 유의한 것으로 정의하였다.

\section{결과}

산모의 임상적 특징은 다음과 같다(Table 1). 대상 산모는 총 
Table 1. Basic Characteristics Related to Mothers

\begin{tabular}{lc}
\hline Variable & Women $(\mathrm{n}=534)$ \\
\hline Maternal age (years) & $33.4 \pm 4.9^{*}(16-48)$ \\
$\begin{array}{l}\text { Time interval between the mother's first visit to } \\
\text { the hospital and the delivery (days) }\end{array}$ & $73.1 \pm 75.4^{*}(1-265)$ \\
Gestational age at first visit (weeks) & $26.4 \pm 10.0^{*}(4-40)$ \\
Route of first visit & $354(66.3)$ \\
$\quad$ Out-patient department & $180(33.7)$ \\
Direct transfer to delivery room & $49(9.2)$ \\
Pregnancy following IVF-ET & $82(15.4)$ \\
Multiple gestation pregnancy & $4(0.8)$ \\
\hline Twin & $128(24.0)$ \\
\hline Triple & $237(44.4)$ \\
Delivery & $169(31.7)$ \\
\hline Vaginal delivery & \\
\hline Elective cesarean section without labor & \\
\hline Emergency cesarean section &
\end{tabular}

Values are presented as mean \pm standard deviation (range) or number (\%). Abbrevation: IVF-ET, in vitro fertilization and embryo transfer.

*Maternal age, time interval between the mother's first visit to the hospital and the delivery and gestational age are described as mean \pm standard deviation.

Table 2. Primary Reasons for Transfer of Mothers

\begin{tabular}{|c|c|}
\hline Variable & Women $(n=534)$ \\
\hline Fetal problems* & $91(17.0)$ \\
\hline Underlying diseases of mothers & $101(18.9)$ \\
\hline Obstetrics diseases $^{\dagger}$ & $27(5.1)$ \\
\hline Other diseases $^{\ddagger}$ & $74(13.9)$ \\
\hline Rupture of membranes & $54(10.1)$ \\
\hline Preterm labor & $50(9.4)$ \\
\hline Gestational hypertension & $50(9.4)$ \\
\hline Incompetent internal os of the cervix & $35(6.6)$ \\
\hline Gestational diabetes & $30(5.6)$ \\
\hline Placenta previa & $27(5.1)$ \\
\hline Multiple pregnancy & $25(4.7)$ \\
\hline Vaginal bleeding & $9(1.7)$ \\
\hline Etc. & $62(11.6)$ \\
\hline
\end{tabular}

Values are presented as number (\%).

${ }^{*}$ Congenital heart disease, decreased fetal heart rate, fetal arrhythmia, fetal abdominal mass, congenital lung mass, ambiguous genitalia, renal agenesis, ventriculomegaly, cleft lip and palate, fetal growth retardation, high risk of down syndrome. †Uterine myoma, cervical cancer, endometriosis, adenomyosis, severe pelvic adhesion, ovarian cyst, vulvovaginal candidiasis.

'Takayasu's arteritis, epilepsy, systemic lupus erythematosus, syphilis, pulmonary tuberculosis, leukemia, panic disorder, thyroid disease, thrombocytopenia, arrhythmia, moyamoya disease, fever.

${ }^{5}$ Hospital employee, no prenatal care, in vitro fertilization and embryo transfer (IVF-ET) at our hospital, one of the twins died, follow up hospital are unavailable, pregnant women wanted, illegal immigrants, pregnancy from sexual violence.
534명이었고 이들의 평균 나이는 33.4세, 입원 후 분만까지의 기간은 평균 73.1 일, 첫 방문 시 평균 재태연령은 26.4 주였다. 전원 경로는 외래 $66.3 \%$, 분만실로 직접 전원이 $33.7 \%$ 로 외래 를 통해 내원한 경우가 많았다. 임부 중 $9.2 \%$ 가 체외수정을 통 한 임신이었고 $15.4 \%$ 가 쌍둥이, $0.8 \%$ 가 삼둥이를 분만하였다. 분만 방식은 질식분만 $24.0 \%$, 예정된 제왕절개술 $44.4 \%$, 응급 제왕절개술 $31.7 \%$ 로 제왕절개술의 빈도가 높았다. 산모가 본 센터로 전원된 이유는 태아 이상이 $17.0 \%$, 산모의 비산과적 기 저 질환이 $13.9 \%$, 산과적 기저 질환이 $5.1 \%$ 를 차지하였고 그 외 대부분은 조기양막파열(10.1\%), 조기진통 $(9.4 \%)$, 임신성 고 혈압(9.4\%), 자궁경부무력증(6.6\%) 등과 같이 현재 임신과 연 관된 문제들이었다(Table 2). 태아 이상으로는 태아성장지연이 $33.0 \%$ 였으며 그 외는 산전 진찰에서 발견된 선천성 심질환, 뇌 기형, 신장 질환, 복부 및 폐의 종괴 및 기형, 태아의 부정맥, 모 호한 성기, 구순구개열, 태아 수종 등이 있었다(Table 3). 산모 들은 기저 질환을 이유로 전원되기도 하였고 다른 이유로 전원 되었다가 본원에서 기저 질환이 진단된 경우도 있었다. 산모의 기저 질환은 총 117 건으로 산과적 기저 질환이 $35.9 \%$ 로 가장 높았고 그 외 갑상선 질환이 $17.1 \%$ 로 높은 비율을 차지하였으 며, 고혈압, 산모의 감염, 당뇨, 정신과 질환, 경련 등이 있었다

\section{Table 3. Fetal Problems that Caused the Transfer of Mothers}

\begin{tabular}{|c|c|}
\hline Variable & Problems $(n=91)$ \\
\hline Fetal growth retardation & $30(33.0)$ \\
\hline Congenital heart disease & $13(14.3)$ \\
\hline Tetralogy of Fallot & $3(3.3)$ \\
\hline Ventricular septal defect & $5(5.5)$ \\
\hline Other heart disease ${ }^{*}$ & $5(5.5)$ \\
\hline Congenital brain malformations & $10(11.0)$ \\
\hline Ventriculomegaly & $6(6.6)$ \\
\hline Other brain disease $^{\dagger}$ & $4(4.4)$ \\
\hline Congenital renal disease & $10(11.0)$ \\
\hline Hydronephrosis & $4(4.4)$ \\
\hline Agenesis of kidney, unilateral & $4(4.4)$ \\
\hline Other kidney disease $^{\ddagger}$ & $2(2.2)$ \\
\hline Fetal abdominal mass & $9(9.9)$ \\
\hline High risk of Down syndrome & $4(4.4)$ \\
\hline Etc. ${ }^{5}$ & $15(16.5)$ \\
\hline
\end{tabular}

Values are presented as number (\%).

${ }^{*}$ Coarctation of the aorta, premature closure of the ductus arteriosus, cardiomegaly, Ebstein's anomaly, single ventricle.

${ }^{\dagger}$ Dandy-Walker malformation, mega cisterna magna, microcephaly.

†Polycystic kidney disease, renal hypoplasia.

${ }^{5}$ Fetal arrhythmia, meconium peritonitis, pleural effusion, ambiguous genitalia, gastroschisis, skeletal dysplasia, congenital diaphragmatic hernia, cleft lip, cleft palate, fetal ear deformity, fetal hydrops. 
Table 4. Primary Underlying Diseases of Mothers

\begin{tabular}{lc}
\hline Variable & Diseases $(\mathrm{n}=117)$ \\
\hline Obstetrics diseases $^{*}$ & $42(35.9)$ \\
Thyroid diseases $^{*}$ & $20(17.1)$ \\
Hypertension $^{\dagger}$ & $9(7.7)$ \\
Infection $^{\dagger}$ & $6(5.1)$ \\
Diabetes mellitus $^{\ddagger}$ & $5(4.3)$ \\
Psychiatric diseases $^{\dagger}$ & $5(4.3)$ \\
Epilepsy $^{\text {Systemic lupus erythematosus }}$ & $3(2.6)$ \\
Etc. $^{\S}$ & $3(2.6)$ \\
\hline
\end{tabular}

Values are presented as number (\%).

*Uterine myoma, cervical cancer, endometriosis, adenomyosis, severe pelvic adhesion, ovarian cyst, vulvovaginal candidiasis.

${ }^{\dagger}$ Pulmonary tuberculosis, rubella, human immunodeficiency virus infection, Hepatitis B virus carrier, maternal group B streptococcus infection, syphilis.

${ }^{\mp}$ Schizophrenia, panic disorder, major depressive disorder, bipolar disease.

'Takayasu's arteritis, epilepsy, systemic lupus erythematosus, syphilis, pulmonary tuberculosis, uterine myoma, cervical cancer, leukemia, panic disorder, thyroid disease, thrombocytopenia, arrythmia, moyamoya disease, fever, Pulmonary artery stenosis, mental retardation, asthma, obesity.

Table 5. Characteristics Related to Mother's Hospitalization, Morbidity and Mortality in the Postpartum Period

\begin{tabular}{lc}
\hline Variable & Women $(\mathrm{n}=534)$ \\
\hline Length of stay after delivery (days) & $4.4 \pm 9.5$ \\
Maternal death after delivery & 0 \\
Maternal admissions to the ICU & $3(0.6)$ \\
Surgical site infection & $5(0.9)$ \\
Other morbid consequences $^{*}$ & $15(2.8)$ \\
\hline
\end{tabular}

Values are presented as mean \pm standard deviation or number (\%).

Abbrevation: ICU, intensive care unit.

*Vaginal prolapse, anemia, thrombocytopenia, liver enzyme elevation, hemothrax, arrhythmia, chronic hypertension.
(Table 4). 분만 후 평균 재원 기간은 4.4 일이었고 분만 후 사 망은 없었으며 3 명의 산모( $0.6 \%)$ 가 중환자실에서 치료를 받았 다. 분만 후 합병증으로는 수술 부위 감염은 $0.9 \%$ 였고, 그 외 질 탈출증, 빈혈, 혈소판 감소증, 간효소 수치의 상승 등이 있었다 (Table 5).

신생아의 임상적 특징은 다음과 같다(Table 6). 신생아들의 평균 재태연령 및 출생체중은 원내 출생아 중 정상 신생아실 에 머물렀던 군은 38.0 주, $3,037.5 \mathrm{~g}$ 이었고, 원내 출생 후 신생 아 중환자실에 입원하였던 군은 34.6주, 2,154.4 g이었으며, 원 외 출생 후 전원되어 입원한 군은 38.5 주, $3,186.8 \mathrm{~g}$ 이었다. 원 내 출생 후 신생아 중환자실에 입원하였던 군이 원내 출생아 중 정상 신생아실에 머물렀던 군이나 원외 출생 후 전원되어 입원 한 군에 비하여 앞에 제시한 바와 같이 출생 시 재태연령 및 출 생체중이 작고(모두 $P<0.001)$, 부당경량아 $(1.4 \%$ vs. $20.5 \%$ vs. $2.8 \%, P=0.008)$ 및 제왕절개술( $73.2 \%$ vs. $83.9 \%$ vs. $16.3 \%$, $P<0.001)$ 로 출생한 비율이 높았고, 1 분과 5 분 아프가점수가 낮았으며(각각, $8.8 \pm 0.6$ vs. $7.7 \pm 1.8$ vs. $8.3 \pm 1.4,9.3 \pm 1.0$ vs. $9.0 \pm 1.5$ vs. $9.8 \pm 0.5$; 모두 $P<0.001) 5$ 분 아프가점수가 7 점 미 만인 환아의 비율이 높았다(4.8\% vs. $2.1 \%, P<0.001)$.

원내 출생 후 신생아 중환자실로 입원한 환아의 $65.5 \%$ 가 입 원이 필요한 재태연령의 조산아라는 이유로 입원하였고, $7.4 \%$ 가 산전에 발견된 선천기형, $5.4 \%$ 가 호흡 곤란을 주소로 입원하 였으며, 고빌리루빈혈증이 주 원인인 경우는 $4.2 \%$ 였다. 원외 출 생 후 전원되어 입원한 군은 $22.0 \%$ 가 호흡곤란, $14.2 \%$ 가 고빌 리루빈혈증을 주소로 전원되었으며, 미숙아 및 선천 기형이 주 원인인 경우는 각각 $6.4 \%, 1.4 \%$ 였다. 선천 기형을 주소로 전원 된 환아 2 명 중 한 명은 산전 초음파에서 복부의 이상 소견이 의 심되었고 출생 후 본원으로 전원되어 복강내 종괴가 확인되었

Table 6. Basic Characteristics of the Babies

\begin{tabular}{|c|c|c|c|c|c|}
\hline Variable & $\begin{array}{l}\text { Babies born in our hospital } \\
\text { (total) }\end{array}$ & $\begin{array}{l}\text { Inbron } \\
\text { (nursery) }\end{array}$ & $\begin{array}{c}\text { Inborn } \\
\text { (admitted to NICU) }\end{array}$ & $\begin{array}{c}\text { Outborn } \\
\text { (admitted to NICU) }\end{array}$ & $P$-value \\
\hline $\mathrm{N}$ & 620 & 284 & 336 & 141 & \\
\hline Birth weight (g) & $2,558.9 \pm 742.5$ & $3,037.5 \pm 470.9(2,250-4,610)$ & $2,154.4 \pm 687.8(400-4,310)$ & $3,186.8 \pm 590.4(1,780-5,200)$ & $<0.001$ \\
\hline Sex (male) & $339(54.7)$ & $159(56.0)$ & $180(53.6)$ & $83(58.9)$ & 0.669 \\
\hline 1-minute Apgar score & $8.2 \pm 1.5$ & $8.8 \pm 0.6$ & $7.7 \pm 1.8$ & $8.3 \pm 1.4$ & $<0.001$ \\
\hline 5-minute Apgar score & $9.4 \pm 1.2$ & $9.3 \pm 1.0$ & $9.0 \pm 1.5$ & $9.8 \pm 0.5$ & $<0.001$ \\
\hline 5-minute Apgar score lower than 7 & $16(2.6)$ & $0(0.0)$ & $16(4.8)$ & $3(2.1)$ & $<0.001$ \\
\hline
\end{tabular}

Values are presented as mean \pm standard deviation (range) or number (\%).

Abbreviations: SGA, small for gestational age; C-sec, cesarean section. 
으며 최종 난소낭종으로 진단되었다. 다른 한 명은 산전 초음 파에서 수신증이 의심되었으며 출생 후 좌신의 요관신우접합 부 폐쇄에 의한 수신증으로 진단되었다. 저혈당 및 기타 원인 을 제외하고 양 군 간에 주 원인의 빈도에 유의한 차이가 있었 다(Table 7).
신생아 중환자실로 입원하였던 신생아들의 임상적 특징 및 예

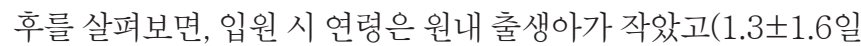
vs. $7.0 \pm 7.6$ 일, $P<0.001)$, 입실 체온 $\left(36.8 \pm 0.4^{\circ} \mathrm{C}\right.$ vs. $36.9 \pm 0.7^{\circ} \mathrm{C}$, $P=0.280)$ 및 입실 시 $36.5^{\circ} \mathrm{C}$ 미만의 저체온을 보인 환아의 비율 ( $13.7 \%$ vs. $14.2 \%, P=0.717)$ 은 두 군 간에 차이가 없었다. 원내

Table 7. Primary Reasons for Admission of Babies to Neonatal Intensive Care Unit

\begin{tabular}{|c|c|c|c|c|}
\hline Variable & Total & Inborn (admitted to NICU) & Outborn (admitted to NICU) & $P$-value \\
\hline Prematurity & $229(48.0)$ & $220(65.5)$ & $9(6.4)$ & $<0.001$ \\
\hline Dyspnea or tachypnea & $49(10.3)$ & $18(5.4)$ & $31(22.0)$ & $<0.001$ \\
\hline Hyperbilirubinemia & $34(7.1)$ & $14(4.2)$ & $20(14.2)$ & $<0.001$ \\
\hline Antenatally detected congenital abnormalities & $27(5.7)$ & $25(7.4)$ & $2(1.4)$ & 0.009 \\
\hline Gastrointestinal problems & $14(2.9)$ & $3(0.9)$ & $11(7.8)$ & $<0.001$ \\
\hline Fever & $13(2.7)$ & $0(0.0)$ & $13(9.2)$ & $<0.001$ \\
\hline Symptoms of upper respiratory infection & $12(2.5)$ & $0(0.0)$ & $12(8.5)$ & $<0.001$ \\
\hline Abnormal appearance & $12(2.5)$ & $4(1.2)$ & $8(5.7)$ & $<0.001$ \\
\hline Cyanosis or desaturation & $11(2.3)$ & $1(0.3)$ & $10(7.1)$ & $<0.001$ \\
\hline Hypoglycemia $^{*}$ & $12(2.5)$ & $10(3.0)$ & $2(1.4)$ & 0.569 \\
\hline Seizure & $6(1.3)$ & $0(0.0)$ & $6(4.3)$ & $<0.001$ \\
\hline Etc. ${ }^{\dagger}$ & $58(12.2)$ & $41(12.2)$ & $17(12.1)$ & - \\
\hline Total & $477(100.0)$ & $336(100.0)$ & $141(100.0)$ & - \\
\hline
\end{tabular}

Values are presented as number (\%).

${ }^{*}$ Glucose $<50 \mathrm{mg} / \mathrm{dL}$.

'Low birth weight, home delivery, hypothermia, no prenatal care, bradycardia, maternal infection, thrombocytopenia (platelet count $<150,000 / \mu \mathrm{L}$ ).

Table 8. Clinical Characteristics of Babies Admitted to Neonatal Intensive Care Unit by Subgroups According to Place of Birth

\begin{tabular}{|c|c|c|c|c|c|}
\hline Variable & $\begin{array}{c}\text { Total } \\
(\mathrm{n}=477)\end{array}$ & $\begin{array}{c}\text { Inborn } \\
\text { (admitted to NICU, } \mathrm{n}=366 \text { ) }\end{array}$ & $\begin{array}{l}\text { Outborn } \\
\text { (admitted to NICU, } n=141 \text { ) }\end{array}$ & $P$-value & $P$-value* \\
\hline Age at admission (days) & $3.0 \pm 5.1$ & $1.3 \pm 1.6$ & $7.0 \pm 7.6$ & $<0.001$ & $<0.001$ \\
\hline Body temperature on admission $\left({ }^{\circ} \mathrm{C}\right)$ & $36.8 \pm 0.5$ & $36.8 \pm 0.4$ & $36.9 \pm 0.7$ & 0.280 & 0.201 \\
\hline Lower than $36.5^{\circ} \mathrm{C}$ & $66(75.4)$ & $46(13.7)$ & $20(14.2)$ & 0.717 & 0.239 \\
\hline Respiratory support & $52(31.9)$ & $117(34.8)$ & $35(24.8)$ & 0.014 & 0.001 \\
\hline Nasal prong & $1(0.2)$ & 0 & $1(0.7)$ & - & - \\
\hline HHHFNC & $64(13.4)$ & $45(13.4)$ & $19(13.5)$ & - & - \\
\hline CPAP & $29(6.1)$ & $25(7.4)$ & $4(2.8)$ & - & - \\
\hline NIPPV & $13(2.7)$ & $12(3.6)$ & $1(0.7)$ & - & - \\
\hline CV & $15(3.1)$ & $11(3.3)$ & $4(2.8)$ & - & - \\
\hline HFOV & $30(6.3)$ & $24(7.1)$ & $6(4.3)$ & - & - \\
\hline Days of respiratory support (days) & $16.3 \pm 22.8$ & $18.8 \pm 25.4(1-141)$ & $8.4 \pm 6.6(2-31)$ & $<0.001$ & 0.751 \\
\hline BPD & $14(2.9)$ & $13(3.9)$ & $1(0.7)$ & 0.048 & 0.341 \\
\hline IVH & $5(1.1)$ & $4(1.2)$ & $1(0.7)$ & 0.537 & 0.110 \\
\hline Duration of hospital stay (days) & $23.0 \pm 22.5$ & $26.0 \pm 23.9(1-188)$ & $15.8 \pm 16.9(2-134)$ & $<0.001$ & 0.004 \\
\hline In-hospital mortality & $14(2.9)$ & $12(3.6)$ & $2(1.4)$ & 0.204 & 0.588 \\
\hline
\end{tabular}

Values are presented as mean \pm standard deviation (range) or number (\%).

Abbreviations: HHHFNC, heated, humidified high-flow nasal cannula; CPAP, continuous positive airway pressure; NIPPV, non-invasive positive pressure ventilation; CV, conventional intermittent mandatory ventilation; HFOV, high-frequency oscillatory ventilation; BPD, bronchopulmonary dysplasia; IVH, intraventricular hemorrhage.

${ }^{*}$ Adjusted for gestational age and birth-weight deviation. 
출생아가 원외 출생아에 비해서 호흡 보조를 필요는 하는 빈도 가 높았으며(34.8\% vs. $24.8 \%, P=0.014)$, 호흡 보조 기간 또한 길었다(18.8일 vs. 8.4일, $P<0.001$ ). 원내 출생아에서 기관지폐 이형성증이 진단된 비율이 높았고(3.9\% vs. $0.7 \%, P=0.048)$, 입 원 기간 또한 길었으나(26.0일 vs. 15.8 일, $P<0.001$ ), 뇌출혈의 빈도(1.2\% vs. $0.7 \%, P=0.537)$ 와 사망률의 차이는 없었다(3.6\% vs. $1.4 \%, P=0.204)$. 출생체중과 재태연령을 포함하여 각 항목 에 영향을 주는 인자들을 보정하였을 때 입원 시 호흡 보조가 필 요했던 비율은 원내 출생아가 여전히 더 높았으며 $(P=0.001)$, 재 원 기간 또한 원내 출생아에서 길었으나 $(P=0.004)$ 호흡 보조 기 간 $(P=0.751)$, 기관지폐이형성증의 이환 빈도 $(P=0.341)$ 는 유의 한 차이가 없었다(Table 8).

산모의 전원 시점에 따른 신생아의 임상적 특징은 다음과 같 다(Table 9). 1 분기에 전원된 산모는 $17.4 \%, 2$ 분기에 전원된 산모는 $26.8 \%$ 였고 $55.8 \%$ 의 산모가 임신 3 분기에 전원되었다. 산모가 임신 1 분기에 전원된 경우 출생한 신생아의 입원율은 $33.0 \%$, 임신 2 분기에 전원된 경우 $56.7 \%$, 임신 3 분기에 전원 된 경우 $59.8 \%$ 로 산모의 전원 시기가 빠를수록 신생아의 입원 율이 감소하였다 $(P<0.001)$. 또한, 산모가 임신 1 분기에 본원으 로 전원되어 산전 관리를 받다가 출산하였던 신생아들이 산모 가 임신 2 분기 또는 임신 3 분기에 전원된 후 출산한 신생아들에 비해 재태연령 및 출생체중이 증가하였다(각각, $37.2 \pm 3.1$ 주 vs. $35.6 \pm 3.9$ 주 vs. $36.1 \pm 2.6$ 주, $2,818.1 \pm 726.9$ g vs. $2,461.1 \pm$ 829.1 g vs. 2,522.2 $\pm 678.6 \mathrm{~g}$; 모두 $P<0.001)$. 하지만, 부당경 량아의 비율(7.3\% vs. $9.4 \%$ vs. $14.5 \%, P=0.062)$, 제왕절개술 의 비율(76.2\% vs. $84.4 \%$ vs. $77.0 \%, P=0.107), 1$ 분 아프가점 수(8.4 \pm 1.4 vs. $8.0 \pm 1.9$ vs. $8.2 \pm 1.3, P=0.530)$, 5 분 아프가점
수(9.5 \pm 1.2 vs $9.2 \pm 1.6$ vs. $9.4 \pm 0.9, P=0.510), 5$ 분 아프가점 수 7점 미만인 환아의 비율(2.8\% vs. $5.6 \%$ vs. $1.7 \%, P=0.140$ ) 은 차이가 없었다.

산모의 전원 시점에서 분만까지의 시간에 따른 신생아의 임 상적 특징은 다음과 같다(Table 10). 전원 후 7일 이내 분만한 산 모는 $27.2 \%$, 전원되어 7 일 이후 28 일 이내 분만한 산모는 $13.9 \%$ 였고, 전원되어 28 일 이후 분만한 산모가 $59.0 \%$ 로 가장 많았다. 처음 산모가 전원된 후 분만까지의 기간이 길어질수록 신생아 의 입원율이 낮았다( $76.4 \%$ vs. $54.9 \%$ vs. $44.9 \%, P<0.001)$. 처 음 산모가 전원된 후 분만까지의 기간이 길어질수록 재태연령 과 출생체중이 증가하였으며(34.9 \pm 2.9 주 vs. $35.8 \pm 3.8$ 주 vs. $36.7 \pm 3.0$ 주, $P<0.001 ; 2,272.6 \pm 684.7 \mathrm{~g}$ vs. $2,492.9 \pm 861.1 \mathrm{~g}$ vs. 2.697.5 $\pm 703.4 \mathrm{~g}, P<0.001)$, 부당경량아의 빈도가 감소하 였다(16.6\% vs. $15.9 \%$ vs. $8.9 \%, P=0.016)$. 제왕절개의 빈도는 차이가 없었으나 $(72.6 \%$ vs. $81.7 \%$ vs. $81.1 \%, P=0.103)$ 전원 후 분만까지의 시간이 길어질수록 응급제왕절개의 빈도는 감소 하였다(57.2\% vs. $37.8 \%$ vs. $26.7 \%, P=0.012)$. 전원 후 분만까 지의 시간이 길어질수록 신생아의 1 분, 5 분 아프가점수는 증가 하였으나(7.9 \pm 1.6 vs. $8.1 \pm 1.6$ vs. $8.3 \pm 1.4, P=0.012$; $9.2 \pm 1.1$ vs. $9.2 \pm 1.5$ vs. $9.5 \pm 1.1, P=0.041), 5$ 분 아프가점수가 7 점 미 만인 환아의 비율( $4.5 \%$ vs. $2.4 \%$ vs. $1.8 \%, P=2.228$ )은 차이가 없었다.

\section{고찰}

본원은 인구 약 147 만 명의 광역시에 위치하는 상급종합병

Table 9. Neonatal Outcomes According to Timing of Transfer of Mothers

\begin{tabular}{|c|c|c|c|c|}
\hline Variable & Duration the 1st trimester & During the 2 nd trimester & During the 3rd trimester & $P$-value \\
\hline Number of mothers & $93(17.4)$ & $143(26.8)$ & $298(55.8)$ & - \\
\hline Number of babies & $109(17.6)$ & $180(29.0)$ & $331(53.4)$ & - \\
\hline Gestational age (weeks) & $37.2 \pm 3.1$ & $35.6 \pm 3.9$ & $36.1 \pm 2.6$ & $<0.001$ \\
\hline Birth weight (g) & $2,818.1 \pm 726.9$ & $2,461.1 \pm 829.1$ & $2,522.2 \pm 678.6$ & $<0.001$ \\
\hline C-sec & $83(76.2)$ & $152(84.4)$ & $255(77.0)$ & 0.107 \\
\hline Emergency C-sec & $12(12.9)$ & $63(44.1)$ & $120(40.3)$ & $<0.001$ \\
\hline 1-minute Apgar score & $8.4 \pm 1.4$ & $8.0 \pm 1.9$ & $8.2 \pm 1.3$ & 0.530 \\
\hline 5-minute Apgar score & $9.5 \pm 1.2$ & $9.2 \pm 1.6$ & $9.4 \pm 0.9$ & 0.510 \\
\hline 5-minute Apgar score lower than 7 & $3(2.8)$ & $8(5.6)$ & $5(1.7)$ & 0.140 \\
\hline
\end{tabular}

Values are presented as mean \pm standard deviation or number (\%).

Abbreviations: SGA, small for gestational age; C-sec, cesarean section. 
Table 10. Neonatal Outcomes According to Time Interval Between Mother's First Visit to the Hospital and Delivery

\begin{tabular}{lcccc}
\hline Variable & $\leq 7$ days & $>7$ days, $\leq 28$ days & $>28$ days & $P$-value \\
\hline Number of mothers & $145(27.2)$ & $74(13.9)$ & $315(59.0)$ & - \\
Number of babies & $157(25.3)$ & $82(13.2)$ & $381(61.5)$ & - \\
Admission rate of babies & $120(76.4)$ & $45(54.9)$ & $171(44.9)$ & $<0.001$ \\
Gestational age (weeks) & $34.9 \pm 2.9$ & $35.8 \pm 3.8$ & $36.7 \pm 3.0$ & $<0.001$ \\
Birth weight (g) & $2,272.6 \pm 684.7$ & $2,492.9 \pm 861.1$ & $2,697.5 \pm 703.4$ & $<0.001$ \\
SGA & $26(16.6)$ & $13(15.9)$ & $34(8.9)$ & 0.016 \\
C-sec & $114(72.6)$ & $67(81.7)$ & $84(26.7)$ & 0.103 \\
\multicolumn{1}{c}{ Emergency C-sec } & $83(57.2)$ & $28(37.8)$ & $8.3 \pm 1.4$ & $<0.001$ \\
1-minute Apgar score & $7.9 \pm 1.6$ & $8.1 \pm 1.6$ & $9.5 \pm 1.1$ & 0.012 \\
5-minutes Apgar score & $9.2 \pm 1.1$ & $9.2 \pm 1.5$ & $2(2.4)$ & 0.041 \\
5-minutes Apgar score lower than 7 & $7(4.5)$ & & 0.228 & \\
\hline
\end{tabular}

Values are presented as mean \pm standard deviation or number (\%).

Abbreviations: SGA, small for gestational age; C-sec, cesarean section.

원으로 지역 사회의 1 차 분만병원 및 2 차 또는 타 3 차 병원에 서 보다 전문적인 치료가 필요한 신생아들의 전원이 이루어지 고 중증 질환의 치료가 가능하다. 동일 광역시 내에 본원을 포함 하여 총 4개의 신생아 중환자실(총 92병상)이 운영되고 있으며, 본원으로 종종 전원이 의뢰되는 인접한 시 · 도의 신생아 중환 자실 병상수는 총 85개다. 본원은 2014년에 보건복지부로부터 고위험 산모 · 신생아 통합치료센터 지정을 받았고, 이미 2009 년부터 신생아 집중치료지역센터 사업 또한 수행 중으로 모체 태아집중치료실 5병상과 신생아집중치료실 34병상을 운영하 면서 매년 500건 이상의 분만을 시행하고 있다. 연구 대상 연 도인 2018년 이전 4개년의 분만건수/신생아 중환자실 입원 건 수는 각각 2014년 590건/504명, 2015년 569건/468명, 2016년 550 건/577명, 2017년 577건/488명으로 5개년 평균 분만 건수 는 568건/년, 평균 신생아 중환자실 입원 건수는 502명/년이었 다. 모체태아집중치료실과 분만실은 전문의 3 인, 간호사 16 인( 모체태아집중치료실 간호사 5인 포함)이 근무하고 있다. 중앙집 중관찰 시스템이 구축되어 있으며 초음파기 3대, 운반형 보육기 3 대, 심전도 모니터 7 대, 심전도 기록기 1대, 맥박산소 계측기 5 대, 태아감시장치 6 대, 도플러 4대, 지속적 수액 주입기 16 대 등 을 보유하고 있다. 분만실은 총 3실로 여러 산모의 동시 분만이 가능하고 분만실 맞은편에 정규 수술실이 위치하며, 필요시 분 만실 내에서도 응급 수술이 가능하다. 신생아 중환자실은 34 병 상을 운영 중이며, 신생아 중환자실 전담 전문의 총 4 인(신생아 분과 전문의 3 인 포함)이 근무하고 있고, 간호사 64 인(전담간호 사 2 인 포함)이 근무하여 간호 2 등급에 해당한다. 또한 연구 기 간 동안 전공의 4 인과 수련의 1 인이 순환 근무하였다. 보유 장비 는 보육기 36 대, 집중치료기 5 대, 고빈도진동환기기를 포함한
(비)침습적기계환기기 20 대, 일산화질소치료시스템 1 대, 저체 온치료시스템 1 대, 지속적 뇌파 감시기 1 대, 초음파기 1 대, 제 세동 및 심전도기록기 1 개, 청력검사기기 1 대, 심전도 모니터 기 38 대, 맥박산소 계측기 63대, 침습적 동맥혈압모니터 38대, 지속적 수액주입기 96대, 광선치료기 20대 등 신생아 중환자 실 장비 기준을 모두 충족하고 있다. 또한 본원은 신생아 관련 타 분과 및 유관과와의 협진이 가능하며 체외막산소공급시스템 (extracorporeal membrane oxygenation) 및 지속적신대체치 료(continuous renal replacement therapy)가 가능하다.

본 연구는 단일 고위험 산모 - 신생아 통합치료센터에서 출산 하였던 산모와 신생아의 임상적 특징 및 치료 결과를 분석하여 정부 지원을 받는 고위험 산모 · 신생아 통합치료센터의 운영이 고위험 임신 및 고위험 신생아의 예후에 미치는 영향을 살펴보 고자 하였다.

2018년 통계 자료에서 산모의 평균 연령은 전국 32.8세, 대전 32.5 세, 세종 32.9 세였으나, ${ }^{7}$ 본원에 방문한 산모의 평균 연령은 33.4세로 그에 비해 높아 고령 산모의 유입을 추측할 수 있다. 산모가 분만실로 직접 전원되었던 경우가 $33.7 \%$ 였고 $66.3 \%$ 의 산모가 외래를 통하여 내원하였는데, 외래를 통하여 입원한 산 모는 분만실로 전원된 산모에 비하여 내원 시 상태가 안정적이 거나 전문 기관의 진료가 필요하지만 응급하지 않은 이유로 외 래로 방문하였을 것으로 즉, 산모의 $1 / 3$ 은 전원 당시 즉각적인 대응이 필요하였다. 산과적 기저 질환 외 산모의 기저 질환으로 갑상선 질환이 가장 많은 부분을 차지하였으나 이것이 전원의 직접적인 이유라기보다는 다른 이유로 전원되었다가 진단된 경 우가 많았다. 또한 산모의 합병증은 신생아의 예후에 중요한 영 향을 미치므로 산모의 산전 건강 상태를 향상시킴으로써 신생 
아의 예후를 향상시키고 신생아 중환자실 입원 기간을 단축시 킬 수 있는데, ${ }^{8}$ 특히 조기양막파열, 임신 중 당뇨, 전자간증은 신 생아의 합병증 및 사망률과 연관이 있다..$^{9-11}$ 본 연구에 참여하 였던 산모들은 산부인과 질환 외에 다양한 내외과적 질환들을 동반하고 있는 비율이 높아 산부인과 뿐만 아니라 여러 진료과 의 협진이 필요하였고 이러한 다학제 진료를 통하여 최적의 치 료 방향을 모색하였던 노력과 적절한 관리가 산모와 신생아의 예후 향상에 기여하였을 것으로 사료된다.

2018년 국내 모성사망자 수는 37명이었고, 모성사망비(출생 아 10 만 명당 모성사망자수)는 11.3 명이었다. ${ }^{12}$ 본원에서 분만 한 산모 중 사망자는 없었으며, 분만 후 중환자실 치료를 받은 산모는 3 명이었다. 한 명은 임신 전 기저 질환은 없었으나 임신 성 당뇨로 본원에서 추적 관찰하였으며, 임신 $34^{+6}$ 주에 분만 후 심부전과 폐부종으로 중환자실에서 집중 치료를 받고 회복되어 퇴원하였다. 다른 한 명은 기저 질환으로 모야모야(Moyamoya) 병을 가진 재태연령 $34^{+5}$ 주 산모가 두통을 주소로 내원하였고 뇌실 내 출혈이 진단되어 응급 제왕절개 시행 후 중환자실 입실 및 신경과로 전과되어 치료받았다. 또 다른 한 명은 임신성 당뇨 병을 가지고 있던 산모로 재태연령 $37^{+5}$ 주에 척수마취하 제왕 절개술 중 두통 호소하여 전신마취 진행 후 제왕절개술을 완료 하였으며, 수술 후 좌 편측 위약감이 발생하여 시행한 뇌컴퓨터 단층 챨영에서 뇌내 출혈로 진단되어 신경과로 전과 후 치료받 았다. 상기 두 산모 모두 재활 치료가 필요하였으나 회복되어 퇴 원하였다. 전 세계적으로 분만 전후 산모가 집중치료실에서 치 료를 받는 경우는 1,000 명의 산모 중 0.7-13.5명으로 흔하지 않 다. 임신 고혈압을 가진 산모의 중환자실 입실률이 가장 높았으 며 그 외의 이유로 분만 출혈, 심장 질환, 호흡기 질환, 감염 등 이 있다. ${ }^{13}$ 본 연구에서 분만 전후 중환자실 치료가 필요한 합병 증의 이환율은 높지 않았으나 3 명의 산모가 사망까지도 이를 수 있는 합병증을 격었는데 이들에서 위험 요인에 대한 조기 진단 및 관리, 적절한 치료가 예후 개선에 도움이 되었을 것이다.

분만 후 합병증 중 수술 부위 감염은 5 명 $(0.9 \%)$ 이었는데 이는 타 연구의 2-7\%에 비하여는 낮은 수치이다. ${ }^{14}$ 제왕절개술 후 수 술 부위 감염은 수술 전 항생제 사용, 수술 시간, 이전 제왕절개 여부, 비만과 전자간증 등의 영향을 받으므로, 적절한 산전 관리 를 통하여 비만과 전자간증을 조절하고 수술 전 예방적 항생제 사용, 수술 시간 단축 등을 통하여 수술 부위 감염의 빈도를 낮 출 수 있을 것이다. ${ }^{15,16}$

1 차 또는 2 차 의료기관에서는 조산아 치료를 위한 인력, 시설 및 장비 등 인프라가 부족하기 때문에, 조산의 대부분은 3 차 의 료기관에서 이루어진다. 본원에서 출생한 신생아의 출생체중과 재태연령이 원외 출생아에 비해 낮은 것은 그 이유 때문일 것이
며, 이는 지역 내 1 차 분만병원 등으로부터 조산이 예견되는 산 모의 전원이 활발히 이루어지고 있음을 반영하는 지표이다.

신생아 중환자실 입실 시 신생아의 체온은 사망률에 유의한 영향을 준다. 입실 시 체온이 $36.5-37.5^{\circ} \mathrm{C}$ 인 경우 사망률이 가 장 낮았고, 체온이 $36.0-36.4^{\circ} \mathrm{C}, 35.0-35.9^{\circ} \mathrm{C}, \angle 35.0^{\circ} \mathrm{C}$ 일 때 사 망률이 각각 1.38 배, 1.44 배, 1.86 배 증가하였으며, 입원 시의 저체온은 $\mathrm{BPD}$, 폐고혈압, 패혈증, 폐출혈, 공기 누출, 경련, 3 단 계 이상의 뇌실 내 출혈, 미숙아 망막증과 이에 대한 수술 필요 도를 증가시킨다는 결과가 보고된 바 있다. ${ }^{17}$ 입실 시 체온은 원 내 출생아에서 신생아 소생술을 시행하는 시간과 수술실 또는 분만실에서 신생아 중환자실로 이동하는 시간 사이의 체온 유 지 정도를 나타내는 반면, 원외 출생아에서는 전원 오는 동안의 체온 유지 정도를 반영하게 된다. 신생아 소생술 시 고체온보다 는 저체온이 유발되는 경우가 더 많고 원외 출생아의 경우 발열 을 주소로 내원하는 경우가 포함되어 각각 입실 시 체온 평균 수 치에 영향을 미칠 가능성이 있으므로, 입실 시 체온이 $36.5^{\circ} \mathrm{C}$ 이 하인 경우를 따로 조사하였을 때 원내 출생아에서 입실 시 저체 온인 경우는 $13.7 \%$, 원외 출생아의 경우 $14.2 \%$ 였으며 두 군 간 에 유의한 차이는 없었다. 그러나 $14 \%$ 내외의 원내 및 원외 출 생아가 저체온 상태에서 신생아 중환자실로 입실하였다는 것은 신생아 초기 처치 및 이송 단계에서 체온 관리의 개선이 필요하 다는 것을 의미한다.

호흡 문제가 원외 출생아의 입원 원인 중 가장 높은 비율을 차 지하였으며, 원내 출생아의 입원 원인 중 두 번째로 높은 비율을 차지하였다. 태아의 호흡과 순환은 태반에 의존하고 출생 후에 는 적절한 태아-신생아 전이 과정이 필요한데 이 과정이 늦어 지는 경우 호흡 문제가 발생할 수 있다. ${ }^{18}$ 따라서 출생 후 신생 아의 호흡 양상을 면밀히 감시하는 것이 필요하고 필요에 따라 경피적 산소포화도 감시 또한 고려하여야 하며, 적절한 호흡 보 조 방법에 대한 숙지도 필요하다. 외부 출생아가 전원 오는 동안 호흡 보조를 필요로 하는 경우도 있었는데, 대부분의 외부 출생 아는 산소포화도 감소에 대한 조치로써 비관 또는 안면 마스크 로 산소를 공급하면서 이송되었고 일부에서 기관 삽관 후 이송 되었다. 전원 전 기관 삽관까지 필요한 경우는 흔하지는 않으나 대부분의 1 차 산부인과 의원에는 소아청소년과 전문 인력이 없 다는 점을 고려할 때, 분만을 진행하는 1차 산부인과 의료진에 게 신생아 초기 처치 및 소생술에 관한 교육이 반드시 필요하다.

원외 출생아에 비해 원내 출생아에서 호흡 보조가 필요한 환 아가 더 많았고 호흡 보조 기간도 길었으며, $\mathrm{BPD}$ 비율이 높았 고 입원 기간이 길었다. 이것은 원내 출생아가 원외 출생아에 비 하여 재태연령 및 출생체중이 더 작기 때문일 것이며, 출생체중 과 재태연령을 포함하여 각 항목에 영향을 주는 인자들을 보정 
한 후에는 호흡 보조의 필요성 및 재원 기간에만 차이가 있었고 호흡 보조 기간과 $\mathrm{BPD}$ 빈도에는 차이가 없었으며 뇌출혈과 사 망률은 양 군 간의 유의한 차이가 없었다. 2004년 미국에서 시 행된 재태연령 23-32주로 출생한 신생아를 대상으로 한 연구 에 따르면 외부에서 출생 후 전원된 아기들에서 원내 출생아보 다 3단계 이상의 심한 뇌실 내 출혈의 빈도가 유의하게 높았다 고 하였으나, ${ }^{19}$ 본 연구에서는 뇌실내 출혈의 빈도에 차이는 없 었다. 선행 연구와 본 연구의 결과가 다른 것은 본 연구에서 외 부 출생아의 재태연령 및 출생체중이 선행 연구의 대상군보다 크기 때문인 것으로 보인다.

응급 제왕절개술 여부, 재태연령과 출생체중은 신생아의 생 존율과 합병증에 중요한 영향을 미친다. ${ }^{20}$ 본 연구에서는 산모 의 전원 시점이 빠를수록 응급 제왕절개술의 빈도가 감소하고 신생아의 입원율이 유의하게 감소하며 출생한 신생아의 재태연 령과 출생체중이 증가하였다. 또한, 산모의 전원 후 분만까지의 시간이 증가할수록 응급 제왕절개술의 빈도, 신생아의 입원율 및 부당경량아의 비율이 감소할 뿐만 아니라 재태연령과 출생 체중, 1 분 및 5 분 아프가점수는 증가하였다. $55.8 \%$ 의 산모가 임 신 3 분기에 전원되었는데, 이들 중에는 증상이 갑자기 발생하여 전원된 경우도 있지만 이상 징후를 빨리 인지하지 못하여 뒤늦 게 전원된 경우도 있다. 후자의 경우 산모의 이상 소견이 더 일찍 발견되어 산모가 적절한 시기에 전원된 후 적절한 산전 관리를 받았다면 그 산모들로부터 출생한 신생아의 예후를 향상시키는 데 도움이 되었을 것이다. 전원 후 분만까지의 시간이 28 일 이상 이었던 산모들은 다음과 같은 이유로 인해 추적 관찰 기간이 길 었다. 태아의 선천 기형이 일찍 발견되어 분만 후 신생아 관리를 위해 전원되었으나 분만과 관련된 응급 상황이 발생하지 않은 경우로, 태아의 구순열과 같이 만삭에 자연 진통이 올 때까지 임 신을 유지하는 데 큰 영향을 주지 않는 선천 기형이 그 예이다. 그와 달리 자궁경관 무력증과 조기 진통이 있어 맥도날드 자궁 경관 봉축술과 자궁 수축 억제제 투여로 임신 기간을 연장한 경 우도 있다. 전자의 경우 임신 기간 동안 본원에서 시행한 진료는 기본적인 산전 진찰에 준하므로 신생아의 재태연령과 출생체중 증가에 미치는 영향은 제한적이며 후자의 경우 전원 후 산모에 게 행한 치료가 임신 기간을 연장시킴으로써 신생아의 재태연 령과 출생체중을 증가시키는 데 기여하였을 가능성이 큰 바, 이 들의 차이를 결과 해석 시 유념하여야 한다.

임신 3 분기로 진행할수록 태아의 재태연령 및 출생체중이 더 증가됨에도 불구하고 임신 1 분기에 내원한 산모에서 출생한 신 생아의 재태연령과 출생체중이 더 큰 것은 산모가 일찍 내원하 여 고위험 산모 전문 진료 기관의 관리를 받음으로써 임신 기간 을 연장할 수 있었음을 의미한다. 전원 후 산모가 적절한 치료를
받을 수 있는 기간을 증가시키는 것은 산모의 건강 상태를 향상 시킬 뿐만 아니라, 조산이 예상되는 산모에게 산전 스테로이드 또는 산전 마그네슘 치료를 함으로써 조산아에서 빈도가 높은 신생아 호흡곤란증후군 또는 뇌손상의 위험을 감소시켜 신생 아 유병률을 낮추는 데도 기여할 수 있다. ${ }^{21}$ 따라서 응급 상황 전 에 고위험 산모를 전원하는 것은 산모뿐만 아니라 태아에게 필 요한 처치를 위한 시간 또한 확보할 수 있고 임신 기간을 유의하 게 연장시킬 수 있다는 데 큰 의미가 있다. 다만, 본원에서 추적 관리를 받으면서 시행한 진료가 모두 신생아의 예후에 직접적 인 영향을 미치는 것은 아니므로, 산모의 전원 시점 및 전원부터 분만까지의 시간과 신생아의 예후에 연관성에 대한 결과를 해 석할 때 이 점을 고려해야 한다. 또한 전원 후 분만까지의 시간 이 길어지는 것 자체가 시간이 흐름으로써 재태연령이 증가하 는 과정을 포함하고, 재태연령이 증가할수록 태아의 체중은 증 가하게 되는 점도 고려해야 한다.

국내 연구 중에는 본 연구와 비교할 만할 연구를 찾을 수 없었 다. 고위험 신생아의 임상적 특징 또는 고위험 산모의 임상적 특 징과 관련하여 세분화된 지표를 살펴보는 연구들은 이미 많이 있었으나 국내에서 고위험 산모 · 신생아 통합치료센터의 산모 와 신생아의 임상적 특징을 함께 살펴본 연구는 많지 않으므로 본 연구가 그 시작이 될 수 있을 것으로 생각된다. 2015년에 뉴 질랜드에서 시행된 코호트 연구에서, 1 차 의료기관에서 분만 예 정이었던 산모 중 $28.5 \%$ 에서 분만 장소가 상급 기관으로 변경 되었는데 산모가 전원된 이유는 급속 분만이 $25 \%$, 장기간의 양 막파열이 $23.7 \%$ 를 차지하였으며 전원된 산모의 $62.9 \%$ 가 비응 급 상태로 전원되었다. 상급 의료기관에서 분만한 신생아와 일 차 의료기관에서 분만한 신생아의 예후 차이는 없었으나, 상급 의료기관에서 분만한 산모의 합병증 비율이 더 높았다. ${ }^{22}$ 뉴질 랜드와 우리나라는 의료 체계와 지리적 환경이 다르므로 정확 한 비교는 어렵겠으나, 본원으로 전원 후 24시간 이내에 분만 한 경우를 응급 분만으로 간주한다면 약 $18 \%$ 가 응급에 해당되 어 뉴질랜드에 비해 응급 상태로 전원되는 산모의 비율이 더 낮 았다.

본 연구는 산모가 본원으로 전원된 후 분만까지 이루어져 산 모와 신생아의 자료를 모두 얻을 수 있었던 경우만을 대상으로 하였고 임신 1 분기 또는 2 분기에 전원되었더라도 본원에서 출 산을 완료하지 못하였거나 유산하였거나 임신 20주 이후 임신 중단한 산모는 제외되어, 본 센터로 전원되었던 모든 고위험 임 신의 예후를 평가하기에는 제한점이 있다. 따라서 향후 이들을 모두 포함한 전향적인 연구가 필요하다. 조금 더 장기간의 데이 터를 모아 분석하는 것이 바람직하겠으나 단일 센터의 전반적 인 현황을 살펴보고자 하였으므로 한 해의 데이터로도 본 센터 
에서 치료받은 산모와 신생아의 일반적인 특징을 파악할 수 있 을 것으로 생각된다. 향후 고위험 산모·신생아 통합치료센터 지정 전후의 데이터를 비교하여 그 효과를 살펴보는 후속 연구 가 필요하다. 이상과 같이 고위험 산모를 일찍 진단하여 적절한 시기에 계획된 전원을 통해 고위험 산모·신생아 통합치료센터 로 의뢰하는 것은 산모 및 태아에 대한 통합적이고 전문적인 관 리와 집중 치료를 통해 산모와 신생아의 예후를 향상시키는 데 기여한다고 분석되었다.

\section{Conflict of interest}

No potential conflict of interest relevant to this article was reported.

\section{References}

1) The Executive Committee of Korean Neonatal Network. 2016 Korean Neonatal Network annual report. Cheongju: Korean Centers for Disease Control and Prevention; 2017. Available from: http://www.kdca.go.kr/ gallery.es?mid=a20503020000\&bid=0003\&act=view\&list_no=136678.

2) Statistics Korea. Birth statistics. Daejeon: Statistics Korea; 2018. Available from: https://kosis.kr/publication/publicationThema.do.

3) Kim SH, Lim SJ, Gang HR, Choi EH, Kim YR, Kim AR. Policy support for medical expenses on pregnancy and delivery. Wonju: National Health Insurance Service; 2015. Available from: https://www.nhis.or.kr/nhis/ together/wbhaec07800m01.do?mode=view\&articleNo=116000.

4) Ministry of Health and Welfare. Expansion of support project for highrisk pregnant women's disease. Sejong: Ministry of Health and Welfare; 2017. Available from: http://www.mohw.go.kr/react/al/sal0301vw. jsp?PAR_MENU_ID=04\&MENU_ID=0403\&page=36\&CONT_SEQ=34337 8\&SEARCHKEY=CONTENT\&SEARCHVALUE=\%EA\%B3\%A0\%EC\%9C\%84 \%ED\%97\%98.

5) Jobe AH, Bancalari E. Bronchopulmonary dysplasia. Am J Respir Crit Care Med 2001;163:1723-9.

6) Kim IW. Diagnostic imaging in pediatric central nervous system. Korean J Pediatrics 1996;39:885-93.

7) Choi SE, Yu SH. Exploratory study on birth indicators in Sejong City. Daejeon: Daejeon Sejong Research Institute; 2019. Available from: https://www.dsi.re.kr/board.es?mid=a10101000000\&bid=0001\&act=vi ew\&list_no=18753.

8) Afrasiabi N, Mohagheghi P, Kalani M, Mohades G, Farahani Z. The effect of high risk pregnancy on duration of neonatal stay in neonatal intensive care unit. Iran J Pediatr 2014;24:423-8.
9) Pasquier JC, Rabilloud M, Picaud JC, Ecochard R, Claris O, Gaucherand P, et al. A prospective population-based study of 598 cases of PPROM between 24 and 34 weeks' gestation: description, management, and mortality (DOMINOS cohort). Eur J Obstet Gynecol Reprod Biol 2005; 121: 164-70.

10) Habli M, Levine RJ, Qian C, Sibai B. Neonatal outcomes in pregnancies with preeclampsia or gestational hypertension and in normotensive pregnancies that delivered at 35, 36, or 37 weeks of gestation. Am J Obstet Gynecol 2007;197:406.e1-7.

11) Watson D, Rowan J, Neale L, Battin MR. Admissions to neonatal intensive care unit following pregnancies complicated by gestational or type 2 diabetes. Aust N Z J Obstet Gynaecol 2003;43:429-32.

12) Statistics Korea. Cause of death statistics. Daejeon: Statistics Korea; 2018. Available from: https://kosis.kr/statHtml/statHtml.do?orgld=101\& tblld=DT_1B34E07\&vw_cd=MT_ZTITLE\&list_id=F_27\&seqNo=\&lang_ mode $=$ ko\&language $=$ kor\&obj_var_id $=\& i t m \_i d=\&$ conn_path $=M T \_$ ZTITLE.

13) Pollock W, Rose L, Dennis CL. Pregnant and postpartum admissions to the intensive care unit: a systematic review. Intensive Care Med 2010; 36:1465-74,

14) Opøien HK, Valbø A, Grinde-Andersen A, Walberg M. Post-cesarean surgical site infections according to CDC standards: rates and risk factors. A prospective cohort study. Acta Obstet Gynecol Scand 2007:86:1097102.

15) Zejnullahu VA, Isjanovska R, Sejfija Z, Zejnullahu VA. Surgical site infections after cesarean sections at the University Clinical Center of Kosovo: rates, microbiological profile and risk factors. BMC Infect Dis 2019;1:752.

16) Rauk PN. Educational intervention, revised instrument sterilization methods, and comprehensive preoperative skin preparation protocol reduce cesarean section surgical site infections. Am J Infect Control 2010;38:319-23.

17) Lee NH, Nam SK, Lee J, Jun YH. Clinical impact of admission hypothermia in very low birth weight infants: results from Korean Neonatal Network. Korean J Pediatrics 2019;62:386-94

18) Morton SU, Brodsky D. Fetal physiology and the transition to extrauterine life. Clin Perinatol 2016;43:395-407.

19) Palmer KG, Kronsberg SS, Barton BA, Hobbs CA, Hall RW, Anand KJS Effect of inborn versus outborn delivery on clinical outcomes in ventilated preterm neonates: secondary results from the NEOPAIN trial. $J$ Perinatol 2005;25:270-5.

20) Wen SW, Smith G, Yang Q, Walker M. Epidemiology of preterm birth and neonatal outcome. Semin Fetal Neonatal Med 2004;9:429-35.

21) Robertson B. Corticosteroids and surfactant for prevention of neonatal RDS. Ann Med 1993;25:285-8.

22) Grigg CP, Tracy SK, Tracy M, Schmied V, Monk A. Transfer from primary maternity unit to tertiary hospital in New Zealand-timing, frequency, reasons, urgency and outcomes: Part of the Evaluating Maternity Units study. Midwifery 2015;31:879-87. 